\title{
ERROR ANALYSIS OF WRITING VERBS IN DISCUSSION TEXT
}

\author{
Dadang Solihat \\ Department of English Education, University of Kuningan, Indonesia \\ E-mail: dacu_qta@yahoo.co.id \\ Diah Novianti \\ Department of English Education, University of Kuningan, Indonesia \\ E-mail: diahnovianti1994@gmail.com
}

APA Citation: Solihat, D. \& Novianti, D. (2015). Error analysis of writing verbs in discussion text. English Review: Journal of English Education, 4(1), 75-81

\begin{abstract}
:
The objective of this study is to find out the error types of writing verbs in students' discussion texts and to identify the factors causing verb errors at the fourth semester students of English major in University of Kuningan. The subject of this study is 20 students. The limitation of the problem is to classify the students' errors based on Linville's error types in writing verbs, there are subject-verb agreement errors, verb tense errors, and verb form errors. This research is using qualitative method by collecting data from documents, questionnaires, and interviews. The result showed that the highest error which most students made is subject-verb agreement. Its frequency is 105 errors or $78.95 \%$. The second common error is verb form with 15 errors or $11.28 \%$. The third common error is verb-tense with 13 errors or $9.77 \%$. The factors causing verb errors are interlingual factor and intralingual or developmental factor. It is influenced by the students' lack of knowledge and understanding of the use of verbs.

Key words: subject-verb agreement error, verb tense error, verb form error, interlingual factor, intralingual or developmental factor
\end{abstract}

\section{INTRODUCTION}

Generally, English is taught and assessed in terms of four skills, namely listening, speaking, reading, and writing. Those four skills are divided into two types, namely receptive skills which consist of listening and reading, and productive skills which consist of speaking and writing. All the skills are needed in learning English, because they have their own important role. But, Brown (2000, p. 216) stated that "the most obvious approach to analyze interlanguage is to study the speech and writing of learners." It makes writing needed to learn. Since, writing is the productive skill that involves

grammatical in a structured way.

In writing skills, grammar is a major role to produce sentences in a text. It corresponds with Brown (2001, p. 362) who said that "grammar is the system of rules governing the conventional arrangement and relationship of words in a sentence." The students need to acquire basic grammatical knowledge to write effectively. In grammatical rules, a sentence usually consists of subject, verb, and object. A sentence can be meaningful because there is a verb as word that can express action of the subject. But, some 
students still make errors in writing some verbs in a text.

The fact show that the fourth semester students of English major in University of Kuningan face erroneous in writing verbs. It corresponds with Corder (1981, p. 36) who suggested that "error is described by the application of linguistic theory to the data of erroneous utterances produces by a learner or a group of learners." The students usually make an error in writing verbs especially in discussion text. As mentioned by Linville (2004), the error types of writing verbs are usually found in subject-verb agreement errors, verb tense errors, and verb form errors.

Based on the point of view, the students make error in writing verbs. This is in line with Thornbury (1999, p. 114) who noted that "grammar errors, on the other hand, cover such things as mistakes in verb form and tense." The example is given in terms of a student's writing. The students write about the discussion text entitled "Should we marry someone who supplies us money than someone whom we love?" In that writing activity students wrote, Money and love is something interdependent. Most of students wrote $\underline{i s}$ as the verb on that sentence. The wrong verb belongs to subject-verb agreement error, and the students should have to write, Money and love are something interdependent.

Some errors have been made by the fourth semester students of English major in University of Kuningan indicated that there are causes of error which influence the students' writing. As mentioned by Touchie (1986), there are two major factors cause of errors in second language learning, namely interlingual factors and intralingual or developmental factors.

Related to those cases, this study investigates error analysis of writing verbs in discussion texts made by university students, which focus on finding out the error types of writing verbs and identifying the factors causing verb errors made by the student in writing discussion texts.

\section{METHOD}

In determining the site and participant, the writer uses purposeful sampling. As supported by Creswell (2012, p. 206) "in purposeful sampling, the writer intentionally select individuals and sites to learn or understand the central phenomenon." Purposeful sampling usually applies to both individuals and sites. This study involves 20 of fourth semester students of English major in University of Kuningan. The participants are chosen regarding two reasons. The first is the writer chooses the fourth semester students of English major because the material about discussion text is taught in the fourth semester students of English major. The second is the writer chooses University of Kuningan, since those place is a strategic place for both the writer and the participant to conduct this study.

The data in this research is taken through documents, questionnaires, and interview. The first is documents which are used to give information for the writer to know the problem that is faced by the students on the usage of verbs in writing discussion text. The step in collecting documents of this study is the writer asks permission to the teacher of writing course in English major of University of Kuningan, to collect the students' discussion text as data instrument for this study.

Questionnaires are used to collect the information about factors which is causing the students make verb errors in writing discussion text. According to 
Gay et al. (2012, p. 388), “a questionnaire is a written collection of self-report questions to be answered by a selected group of research participants." The questionnaires of this study use multiple choice questions. The questionnaire consists of some questions to collect the data for identifying the factors causing verb errors made by the student in writing discussion texts. A questionnaire could be easy analyzed by uses Likert Scale from Fraenkel and Wallen (2009, p. 126), namely $5=$ Strongly Agree, $4=$ Agree, 3 = Undecided, 2 = Disagree, $1=$ Strongly Disagree, and closed questions.

The third is interview. It is equally popular to observation in qualitative research. Creswell (2012, p. 217) stated that a qualitative interview happens when writers ask one or more participants general, open-ended questions and record their answers. Gay et al. (2012) added that there are types of interview, namely unstructured interview and structured interview. Hence, this study uses structured interview because the writer prepare a set of questions to acquire the necessary information.

There are a number of steps taken in conducting an error analysis (Gass \& Selinker, 2008). The first is collecting data, when this is typically done with written data. The second is identifying errors, it means finding out the error. The third is classifying errors, to classify the errors into the theme. The fourth is quantifying errors to know the total number of errors. The fifth is analyzing source, and the last is remediate, based on the kind and frequency of an error type, pedagogical intervention is carried out.

\section{RESULTS AND DISCUSSION}

Based on the study, a lot of students made errors in writing verb. Terror types of writing verbs in discussion text, such as subject-verb agreement errors, verb tense errors, and verb form errors. By analyzing the students' discussion text, the writer obtained the results as presented in the following table:

Table 1. Error types of writing verbs

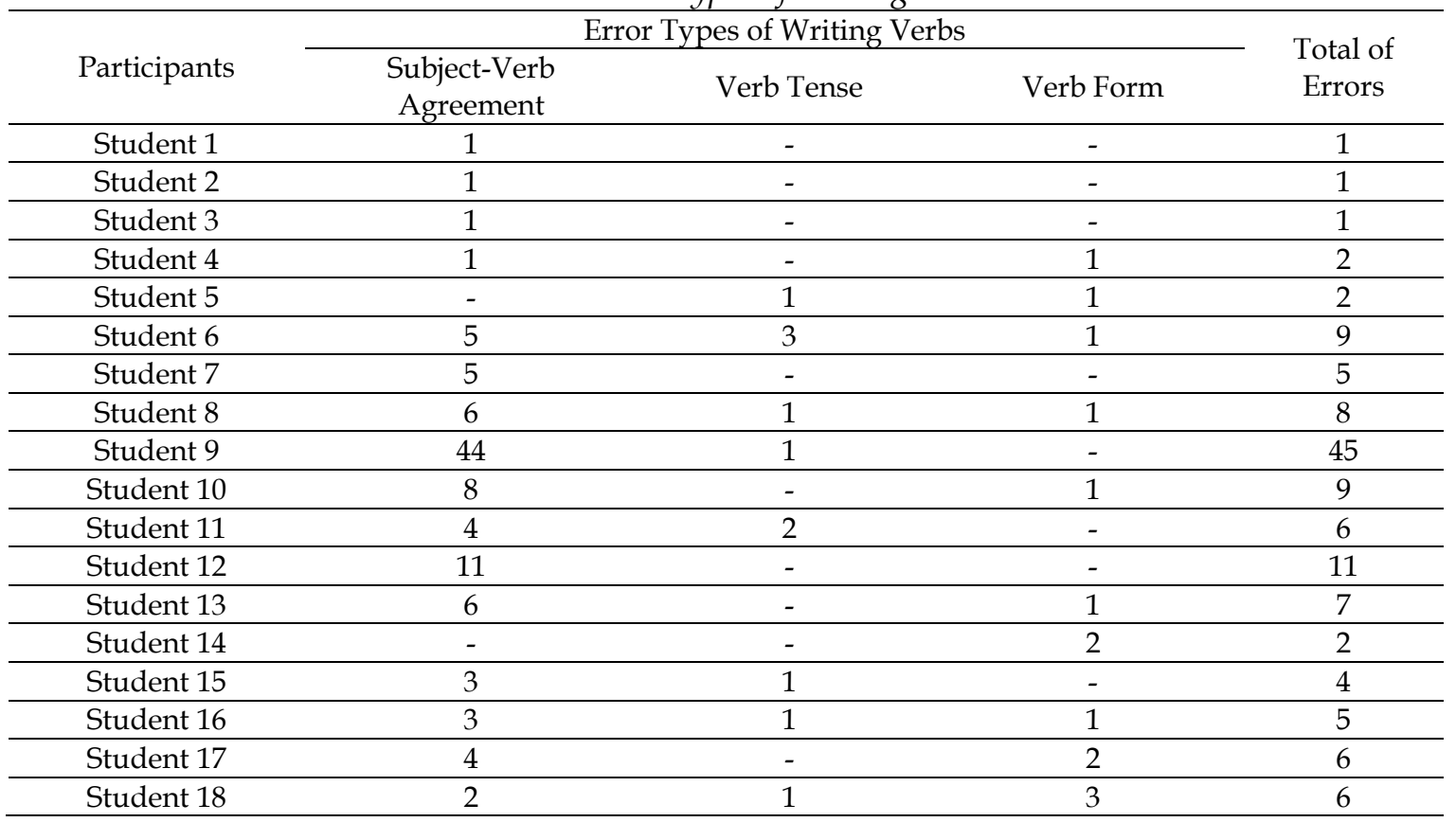




\begin{tabular}{ccccc}
\hline Student 19 & - & 2 & - & 2 \\
\hline Student 20 & - & - & 1 & 1 \\
\hline Total & 105 & 13 & 15 & 133 \\
\hline $\begin{array}{c}\text { Percentage of } \\
\text { Errors }\end{array}$ & $78.95 \%$ & $9.77 \%$ & $11.28 \%$ & $100 \%$ \\
\hline
\end{tabular}

Table 1 described the result of error types of writing verbs from the students' discussion texts. The writer found 133 errors consist of 105 subjectverb agreement errors, 13 verb tense errors, and 15 verb form errors. These table also presented the percentage of subject-verb agreement errors were 78.95
$\%$, verb tense errors were $9.77 \%$, and verb form errors were $11.28 \%$.

Based on the study, a lot of students made errors in writing verb. The writer found error types of writing verbs in discussion text, such as subjectverb agreement errors, verb tense errors, and verb form errors. Some examples are given below:
1) They supplies money for their son. (incorrect) They supply money for their son. (correct)
2) He come from South Korea. (incorrect) He comes from South Korea. (correct)

The first error is basic subjectverb agreement error, the wrong verb is written by the student in the discussion text. The verb supplies, it should have to write supply. Since the subject did not agree with the singular verb. Then, the second error is made in subject-verb agreement using final $-s /-e s$. The wrong verb come should be added by $-s$ because the verb did not agree with the subject in singular pronoun.

1) Financial stills needed to welfare the family. (incorrect)
Financial is still needed to welfare the family. (correct)
2) All the facilities has been guarantee. (incorrect)
All the facilities have been guaranteeing. (correct)

The first verb tense error occurred in passive sentence use the present participle (Azar, 1989). This error produced because the sentence needs verb is. While, the second verb tense error has been guarantee, it should have to write have been guaranteeing, because the subject is plural noun. It belongs to present perfect continuous. According to Azar (1999), the form of present perfect continuous is: have/has + been + -ing (present participle).
1) They will trying hard to make us... (incorrect) They will be trying hard to make us... (correct)
2) Love is place to sharing. (incorrect) Love is place to share. (correct)

The first verb form error produced the incorrect verb will trying, it should have to write will be trying. Since, as explained by Knapp and Watkins 
ENGLISH REVIEW: Journal of English Education Vol. 4, Issue 1, December 2015
ISSN 2301-7554

https://journal.uniku.ac.id/index.php/ERJEE
(2005) the -ing form is used for the progressive tense. Then, the second error occurred in using -ing form. The incorrect verb to sharing should have to write to share, because after to infinitive always followed by verb 1 .

In analyzing causes of error which faced by the fourth semester students of English major in University of Kuningan especially in writing verbs, the writer obtained the data result from two instruments, namely questionnaires and interviews. Those instruments had been used to know the dominant factor which faced by the students. It is between interlingual and intralingual or developmental factors.

Based on the questionnaires that have been analyzed by the writer, there were two factors causing verb errors in writing discussion text made by fourth semester students of English major in University of Kuningan, namely interlingual factors and intralingual or developmental factors. However, there is a dominant factor which caused verb errors in their writing. The writer obtained the results in the following table.

Table 2. The factors of students' errors

\begin{tabular}{clcc}
\hline No. & \multicolumn{1}{c}{ Category } & Total & Average \\
\hline 1. & Interlingual Factor & 628 & $48 \%$ \\
\hline 2. & Intralingual or Developmental Factor & 669 & $52 \%$ \\
\hline \multicolumn{2}{c}{ Total } & 1297 & $100 \%$ \\
\hline
\end{tabular}

Table 4.5 presented the factors of students' error in writing verbs in their discussion text. The results showed that interlingual factor is 628 representing with the percentage is $48 \%$, and intralingual or developmental factor is 669 representing with the percentage is $52 \%$. Related to those result, the writer assumed that the dominant factor which caused the students made errors in writing verb is intralingual or developmental factor. Meanwhile, after analyzing interviews from the student's responses, the writer found the factor which caused verb errors in students' discussion texts. Based on the student's responses for the first question, the writer assumed that interlingual factor is one of the causes of error in writing verbs. It corresponds with Touchie (1986) who said that the native language of student plays a significant role in learning a second language. The students did not know the verb in English, it made them write verb by using their native language. One of the students also still made errors when using the ending $-s$ in third person singular pronoun. This is in line with Noori, Shamary, and Yasin (2015) who assumed that some students usually omit such $-s$ when the subject is singular.

The interview data result from the second question, the writer thought that interlingual factor has a role in causing verb errors. According to Brown (2000), the beginning stage of learning a second language is the negative influence from the native language. The students still made error in translating words in Indonesian into English.

From the result of interview for the third questions, the writer found that intralingual or developmental factor is a major factor in second language learning. It showed from the student's responses, because there are many statements who explained that intralingual or developmental factor 
influence the student's writing discussion text. As explained by Brown (2000), intralingual occurred because the negative influence from the target language itself. A lot of students still confused in using -ed or $-s$ form, and in deciding tenses in a text.

\section{CONCLUSION}

Error types of writing verbs which are found in students' discussion texts consist of subject-verb agreement errors, verb tense errors, and verb form errors. The highest until the lowest frequency and percentage verb errors derives from subject-verb agreement (105 errors or $78.95 \%)$, verb form (15 errors or $11.28 \%$ ), and verb tense (13 errors or $9.77 \%$ ).

There are two factors causing verb errors namely interlingual factor and intralingual or developmental factor. The writer found that intralingual or developmental factor is the dominant factor which is made by the 20 of fourth semester students of English major in University of Kuningan when they produce verb errors in their discussion texts. At the study, $48 \%$ of the questionnaire results showed that interlingual factor is the lowest percentage, and $52 \%$ questionnaire results showed that intralingual or developmental factor is the highest percentage.

Interlingual factor and intralingual or developmental factor causing the students made verb errors. However, the dominant factor is intralingual or developmental factor which is influenced by the students' lack of knowledge and understanding of the usage of verbs. In other words, they made an error in using subject-verb agreement, deciding verb form like $-s /-$ es form, -ed form, and -ing form, and the students also still confuse in using tenses especially in discussion texts.

\section{REFERENCES}

Azar, B. S. (1999). Understanding and using English grammar (3 ${ }^{\text {rd }}$ ed.). New Jersey: Pearson Education.

Brown, H. D. (2004). Language assessment: Principles and classroom practice. New York: Longman.

Brown, H. D. (2001). Teaching by principles: An interactive approach to language pedagogy ( $2^{\text {nd }}$ ed.). London: Addison Wesley Longman, Inc.

Brown, H. D. (2000). Principles of language learning and teaching (4th ed.). London: Addison Wesley Longman, Inc.

Corder, S. P. (1981). Error analysis and interlanguage. London: Oxford University Press.

Creswell, J. W. (2012). Educational research: Planning, conducting, and evaluating quantitative and qualitative research $\left(4^{\text {th }}\right.$ ed.). Boston, MA: Pearson Education, Inc.

Creswell, J. W. (2009). Research design: Qualitative, quantitative and mixed methods approaches (3rd ed.). Los Angeles: SAGE Publications, Inc.

Creswell, J. W. (1998). Qualitative inquiry and research design: Choosing among five traditions. Los Angeles: SAGE Publications, Inc.

Cynthia, R. (2013, June). Four skills in the English language. Retrieved from Word Press. Retrieved from https:/ / rahelcynthia.wordpress.com/20 13/06/28/four-skills-in-the-englishlanguage/

Djuharie, O. S. (2007). Genre. Bandung: CV. YRAMA WIDYA.

Dulay, H., Burt, M., \& Krashen, S. (1982). Language two. New York: Oxford University Press.

Ellis, R., \& Barkhuizen, G. (2005). Analyzing learner language. Oxford: Oxford University Press.

Eastwood, J. (1994). Oxford guide to English grammar. New York: Oxford University Press. 
ENGLISH REVIEW: Journal of English Education

Fraenkel, J. R., \& Wallen, N. E. (2009). How to design and evaluate research in education (7th ed.). New York: McGraw-Hill.

Gass, S. M., \& Selinker, L. (2008). Second language acquisition: An introductory course ( $3^{\text {rd }} e d$.). New York: Routledge.

Gay, L. R., Mills, G. E., \& Airasian, P. W. (2012). Educational research: Competences for analysis and application. Boston: Pearson Education, Inc.

Gerot, L., \& Wignell, P. (1994). Making sense of functional grammar (1 ${ }^{\text {st }}$ ed.). Sydney: Gerd Stabler.

Harmer, J. (2007). The practice of English language teaching ( $4^{\text {th }} \mathrm{ed}$.). Cambridge: Pearson Education Limited.

Harmer, J. (2004). How to teach writing. Harlow: Pearson Education Limited.

James, C. (1998). Error in language learning and use: Exploring error analysis. London: Longman.

Karim, S. M. S., Fathema, F., \& Hakim, A. (2015). Common errors on the usage of verbs in English composition: A case study of Bangladeshi EFL learners. Asian Journal of Educational Research, 3(2). Retrieved from

http://www.multidisciplinaryjournals.c om/

Knapp, P., \& Watkins, M. (2005). Genre, text, grammar: Technologies for teaching and assessing writing. Sydney: University of New South Wales Press Ltd.

Kothari, C. R. (2004). Research methodology: Methods and techniques. New Delhi: New Age International (P) Ltd., Publishers.

Lightbown, P. M., \& Spada, N. (2006). How language are learned ( $3^{r d}$ ed.). New York: Oxford University Press.
ISSN 2301-7554

https://journal.uniku.ac.id/index.php/ERJEE

Linville, C. (2004). Editing line by line in $S$. Bruce \& B. Rafoth (2 $2^{\text {nd }}$ ed.): ESL writers: A guide for writing center tutors.

Boynton/Cook Publishers: Portsmouth.

Noori, M. A. J. H. A., Shamary, I. H. K. A., \& Yasin, M. S. M. (2015). Investigating subject-verb agreement errors among Iraqi secondary school students in Malaysia. International Journal of Education and Research, 3(5), 433-442. Retrieved from http://www.ijern.com/journal/2015/ May-2015/38.pdf

Pinter, A. (2006). Teaching young language learners. New York: Oxford University Press.

Rohman, F. (2014, April). English text types genre of text. Retrieved from http://fatwarohman.blogspot.co.id/201 4/04/english-text-types-genre-oftext.html

Rohman, F. (2013, November). Discussion text about pros and cons of school uniforms. Retrieved from http:// fatwarohman.blogspot.co.id/201 3/11/discussion-text-about-pros-andcons-of.html

Touchie, H. Y. (1986). Second language learning errors: Their types, causes, and treatment. Austin: University of Texas.

Thornbury, S. (1999). How to teach grammar. London: Pearson Education Limited.

Zhuang, L. (2011). A study of verb errors committed in written English by Chinese college students in Taiwan. Journal of Humanities and Social Science, 7(1), 91-101. Retrieved from http://journal.dyu.edu.tw/dyujo/docu ment/hssjournal/h07-1--91-101.pdf 